
21. Film Schedule, WAC, T5/2, 167/1.

22. Ronald Waldman, memo to H. D. Tel, 13 September 1960, WAC, T5/2,166/1.

23. Controller of Programmes TV, memo, 1 November 1960, WAC, T5/2, 167/1.

24. Pierre Sorlin, European Cinema, European Societies 1939-90 (London: Routledge, 1991), p. 12.

25. Vincendeau, 'Maigret pour toujours?', p. 99.

26. Elizabeth David had published her influential books on Mediterranean food throughout the previous decade (A Book of Mediterranean Food was first published in 1950, French Country Cooking in 1951 and French Provincial Cooking in 1960). Habitat, an interiors shop that imported goods such as earthenware dishes and pasta jars from the Continent, first opened in 1964.

27. The opening lines in full are: 'Sexual intercourse began/In nineteen sixty-three/(Which was rather late for me)/Between the end of the Chatterley ban/And the Beatles' first LP', but popular memory elides the line about the lateness. Philip Larkin, 'Annus Mirabilus' (first published in High Windows, 1967), Collected Poems (London: Marvell Press/Faber \& Faber, 1988), p. 167.

28. Dominic Sandbrook, Never Had It So Good: A History of Britain from Suez to the Beatles (London: Abacus, 2005); Dominic Sandbrook, White Heat: A History of Britain in the Swinging Sixties (London: Abacus, 2006); see also Richard Davenport-Hines, An English Affair: Sex, Class and Power in the Age of Profumo (London: William Collins, 2013); Frank Mort, Capital Affairs: London and the Making of the Permissive Society (New Haven, CT, and London: Yale University Press, 2010); Christopher Bray, 1965: The Year Modern Britain Was Born (London: Simon \& Schuster, 2014)

\section{Parisian Cinephiles and the Mac-Mahon}

\section{Leila Wimmer}

Paris stands at the centre of the phenomenal passion for film that France has maintained since the first screening of the Cinématographe at the Salon Indien of the Grand Café on the boulevard des Capucines on 28 December 1895. From the silent era to the coming of sound, Paris, the capital of modern art, witnessed an explosion of interest in film typified by the specifically French intellectual fascination for the 'low art' of cinema, especially Hollywood and the work of D. W. Griffith, Thomas H. Ince, Cecil B. DeMille, Charlie Chaplin, Mack Sennett and others. A by-product of modernism, this fascination was from the outset the creation of a cultural elite, ${ }^{1}$ a masculine culture of distinction ${ }^{2}$ firmly embedded in the urban fabric of the city with the unprecedented rise of a cinephilic sociability through a network of critics, film journals, ciné-clubs, specialised theatres and film societies, special film lectures and exhibitions, not to mention the binding role of the Cinémathèque Française created in 1936 by Henri Langlois and Georges Franju. Reignited in the post-war period by New Wave critics and directors, this particular strand of cinephilia has acquired the status of a myth, evoking a specific 'site of memory'3 - Paris in the $1950 \mathrm{~s} .{ }^{4}$ In his authoritative history of cinephilia, Antoine de Baecque defines this type of cinephilia as essentially Parisian. The invention of a gaze and a culture, 'a way of watching films, speaking about them and then diffusing the discourse', Parisian cinephilia 'has the particularity of being located in the original birthplace, the world centre of the cultural legitimation of cinema as an art'. ${ }^{5}$

The story of the Cinémathèque is already well rehearsed ${ }^{6}$ and here I want to focus on another iconic site of Parisian cinephilia, the Mac-Mahon, a still functioning cinema that bears the name of the avenue it is situated on in Paris, as well as those who frequented it, the 'Mac-Mahoniens', a particularly extreme and controversial version of the cinephile. Although the Mac-Mahon is rather small, its standing as a cinéma d'art et essai is legendary. It represents a high point in the history of 1950 s and 1960 s cinephilia conceived as a modernist and formalist masculine devotion to Hollywood. The epicentre and last surviving site of an intense cinematic culture, the Mac-Mahon has had a tremendous subterranean influence, even if it is often overlooked, or brushed aside, in histories of the period. The Mac-Mahon offers some suggestive insights into two sets of issues. Firstly, the primordial relationship between cinephile culture and the particular context of Paris, and, secondly, the means by which the high modernist cult of the autonomous artwork that dominated this strand of cinephilia, and which continues to play an important role to this day, took the politics of style to its logical extreme.

Cinephilia first emerged in Paris during the post-World War One silent era when Hollywood asserted its hegemony over French screens and for a whole generation of intellectuals, the cult of cinema, especially American cinema, offered an alternative to 

this almost religious devotion to film was structured around the provocative elevation of the disreputable medium of film into a good object of legitimate culture, the 'Seventh Art', and they set themselves against those cinéphobes who denounced film as a vulgar fairground attraction, in order to promote a radically modern French cinema. ${ }^{7}$ To elevate the cultural status of cinema, this devotion produced a discourse revolving around the theorisation of cinema's specificity, and its aesthetic essence that was crystallised in the abstract and elusive term, photogénie. ${ }^{8}$ This went hand in hand with the first conception of the politique des auteurs. ${ }^{9}$ It should be mentioned at this stage that despite the involvement of women in early French film criticism, this strand of cinephilia remained exclusively related to the masculine domain of elite culture. ${ }^{10}$

This specific mode of reception and the cult of American cinema continued in Paris after World War Two when the influx of Hollywood films banned during the German Occupation ignited a new wave of discourse on film aesthetics. In an echo of the debates of the silent era about medium specificity, the politique des auteurs, and the issue of what exactly constituted mise-en-scène, once again dominated discussion. Cahiers du cinéma became the leading journal of this cinephilic tendency, polemically championing Hollywood directors such as Alfred Hitchcock and Howard Hawks and arguing that cinematic specificity resided in mise-en-scène alone. Providing the basis for a purely aesthetic approach to film, mise-en-scène criticism reached its apogee when the critics Michel Mourlet, Michel Fabre, Jacques Serguine, Jacques Lourcelles and Pierre Rissient gathered around the Mac-Mahon cinema and the now mythical film journal, Présence du cinéma (1959-67). ${ }^{11}$

In post-war Paris, cinemas that were central to cinephilia entered their golden age and cinema attendance remained at its peak until the late 1950s when the arrival of television in French households signalled the beginning of a decline in audiences. Cinephile culture was tied to the social ritual of filmgoing and the space of the cinema auditorium, a communal social experience bound to the projection of celluloid in the dark on the big screen. Therein 'lies the very fascination of the film', noted Roland Barthes, who described leaving the cinema as 'coming out of hypnosis'. ${ }^{2}$ Hence also, perhaps, the idea of cinema as a medium of revelation..$^{13}$ Moussinac had argued in the silent period that one could only become a true cinephile by the assiduous frequentation of cinemas: 'One must frequent cinemas patiently and often. Faith doesn't come all of a sudden. ${ }^{14}$ The sociability of filmgoing was at the core of cinephile culture, since films often became the sites of symbolic battles between different cinephile groups revolving around a specific cinema and a film journal. Cinephilia was thus often defined as a highly localised activity closely connected to particular spaces of consumption. Cinephilic activities generally took place in the centre of the Parisian capital, with geographic clusters developing over the years. ${ }^{15}$ Christophe Gauthier has observed that in the post-war period cinephiles gradually annexed Parisian locations, such as the 5th and 6th arrondissements on the Left Bank, already a hot spot of cinephile activity in the 1920 s with the opening of the Vieux-Colombier (1924), Studio des Ursulines (1926), the Ciné-Latin (1927) and the Cluny-Cinéma (1929), among many others. After the Liberation, the number of cinemas exploded in the capital and Paris had around 350 first-run, second-run, art and experimental cinemas spread throughout the city. While the movie palaces were situated on the Champs-Elysees and along the Grands Boulevards (boulevard des Capucines and boulevard des Italiens in particular), working-class areas from the place de Clichy to the Barbès-Rochechouart Métro station (near Montmartre) were also packed with cinemas; there were 31 in the 18th arrondissement, 18 in the 19 th and 26 in the 20th. ${ }^{16}$ The Cinemathèque Française returned to full activity and the thriving ciné-club movement contributed to the strengthening of the place of cinema in the French intellectual and cultural sphere, especially in the capital. In November 1944 just one ciné-club was known to have existed, by June 1948 there were some 185 , with a membership of over 100,000 by June $1947 .{ }^{17}$ As Christian-Marc Bosséno has observed, film theatres once more became the temples of a new religion and the life of the cinephile a frantic race across Paris from cinema to cinema. ${ }^{18}$

The core audience was now made up of young, urban filmgoers; in a study of French audiences between the years 1957 and 1964, it was argued that 'The young, welleducated, "enlightened fanatic" is replacing the average spectator.'19 The Mac-Mahon, the Studio Parnasse on the Left Bank and the Midi-Minuit on the Grands Boulevards, each hosted its own clan, cinephile tribe or 'chapel' with its own specific denomination: the 'Hitchcocko-Hawksians' and the politique des auteurs, the 'Midi-Minuistes' (from the journal Midi-Minuit fantastique) championing horror and the fantastic, especially the British horror films of Terence Fisher, the 'Mac-Mahoniens' promoting an ultra-formalist agenda through the absolute primacy of mise-en-scène.

\section{The Mac-Mahon}

The fabled Mac-Mahon cinema became the headquarters in the early 1950 s of one of the most formalist strands of post-war Parisian cinephilia which, in pushing the definition of cinema in terms of its formal qualities to its extreme, gave rise to the critically controversial term 'Mac-Mahonisme'. Situated on 5 avenue Mac-Mahon near the Arc de Triomphe and the place de L'Etoile on the Right Bank in the 17th arrondissement, and close to the offices of Cahiers du cinéma at 146 avenue des Champs-Elysées, the Mac-Mahon was a small one-screen cinema that had originally been built in 1938 . Requisitioned by German soldiers during the Occupation, it was regularly attended by US troops after the war. The programming of the cinema was highly significant. Its owner, Emile Villion, had decided to show American wartime films in their original English-language version. In the context of intense excitement about Hollywood cinema, the Mac-Mahon thus started to attract Parisian cinephiles shuttling between the Cinémathèque situated on avenue de Messine in the 8 th arrondissement, ${ }^{20}$ the Studio Parnasse on the Left Bank and the first-run film theatres of the Champs-Elysées. In the mid-1950s, a small group of cinephiles from the nearby Lycée Carnot, Pierre Rissient, Michel Fabre and Michel Mourlet, eventually convinced Villion that they be put in charge of programming. Initially concentrating on a handful of Hollywood directors such as Fritz Lang and Joseph Losey, this group of critics began to spread its influence wider in 1960 when the Mac-Mahon was turned into a first-run theatre. At the end of same year, the Cercle du Mac-Mahon ciné-club was founded under the chairmanship of director Joseph Losey. Four large black-and-white photographic portraits of Joseph Losey, 
Fritz Lang, Otto Preminger and Raoul Walsh featured in the lobby of the basement projection hall: 'Losey, Lang, Preminger, Walsh, the four aces of the Mac Mahon'. ${ }^{21}$ In the meantime, the 'Mac-Mahon school' was allowed a platform in Cahiers du cinéma. They set themselves apart from other Cahiers critics through their preference for Walsh and Preminger rather than Hitchcock and Hawks and by their ultra-formalist attachment to mise-en-scène. The absolute primacy of form was theorised with a manifesto published in 1959 in the journal. Signed by Michel Mourlet, it was framed by a statement in italics by the editor, Eric Rohmer, making it clear that although the views expressed were not entirely shared by the journal, he wished to offer it to readers 'without further comment'. This manifesto can now be regarded as the precise moment at which the formalist, modernist and masculine strands of cinephilia reached their peak:

The curtain opens. The house goes dark. A rectangle of light presently vibrates before our eyes. Soon it is invaded by gestures and sound. Here we are absorbed by that unreal space and time. More or less absorbed. The mysterious energy that sustains with varying felicities the swirl of shadow and light and its foam of sound is called mise-en-scène. It is through mise-en-scène that our attention is set, organising a universe, covering the screen - mise-en-scène and nothing else [...] The arrangement of actors and objects, their placement within the frame, this must express everything, as we can see in the supreme perfection of Fritz Lang's two latest films, The Bengal Tiger and The Indian Tomb. $^{22}$

The Mac-Mahoniens' theory of cinema that exalted mise-en-scène was founded on the valorisation of a taste for film as the art of fascination, an aesthetic posture through which this elite group of cinephiles affirmed its distinction and its difference. This radical formalism was linked to Catholicism through the figure of André Bazin and to the counterculture of the literary Right made up of the group of writers dubbed the 'Hussards'. ${ }^{23}$ This group that included Roger Nimier, Jacques Laurent, Antoine Blondin and Michel Déon differentiated themselves from the dominant Left by rejecting the idea of social and political commitment and by professing a sense of disengagement and art for art's sake. In the post-war intellectual context, this was tantamount 'to a declaration of rightwing affiliation'. ${ }^{24}$

This retreat into the confining realm of the aesthetic must also be understood in the context of the cultural changes brought about by rapid technocratic modernisation, the gender politics inaugurated by Simone de Beauvoir with the publication of The Second Sex in 1949 and the Right-Left split with the onset of the Cold War and decolonisation. In cinephile culture, these splits were played out on the terrain of form versus content, the aesthetic versus the political. The ideological debate over Hollywood was particularly intense. Beyond this radical posturing, the fetishisation of mise-en-scène can also be regarded as a defensive reaction against the hegemony of committed approaches to film, particularly those of Marxist film critics such as Georges Sadoul in the prestigious weekly Les Lettres françaises, the neo-surrealists at Positif, and the film journals $L a$ Méthode, Miroir du cinéma, Cinéma and Image et son united by their anti-colonialist articles on the worsening situation in Algeria. ${ }^{25}$
The critical strategy adopted by the proponents of mise-en-scène introduced a radical formalism built upon a highly exclusive counter-canon that exalted the genius of a select group of directors. It conceptualised cinema in terms of its interest in beautiful and violent bodies and dismissed as irrelevant films that didn't 'aim for this sublime' and which were 'content with posing sordid problems'. ${ }^{26}$ In the name of these principles, Michel Mourlet's manifesto paved the way to a reversal of accepted hierarchies of taste as well as a radical overthrow of the Cahiers du cinéma pantheon. Cecil B. DeMille was superior to Alfred Hitchcock, while Orson Welles, one of André Bazin's favourite directors, was deemed another bête noire whose 'aggressive modernism and gratuitous originality conceals an expressionism that is a quarter of a century old'. ${ }^{27}$

At the heart of Mourlet's theory of film was the notion of the spectator being linked to the world of the film in a form of exalted fascination elicited by a classical continuity editing style unhindered by unusual or showy camera angles, framing or montage. Since cinema was the art of physical relationships between actors and setting, it was

a gaze which is substituted for our own in order to give us a world that corresponds to our desires, it settles on faces, on radiant or bruised but always beautiful bodies, on this glory or this devastation which testifies to the same primordial nobility, on this chosen race that we recognise as our own, the ultimate projection of life towards God. ${ }^{28}$

While the politique des auteurs for Cahiers was tied to a certain moral vision (for instance, the idea of the transference of guilt in Alfred Hitchcock) and a conception of cinema as a religious narrative of the real, ${ }^{29}$ it was linked for the Mac-Mahon school to a cinematic aesthetic consisting of the director 'stripping the spectator of any conscious distance to precipitate him in a state of hypnosis sustained by an incantation of gestures, looks, tiny movements of the face and the body and vocal inflexions.' ${ }^{30}$ Hence the idea that mise-en-scène should be invisible. While this followed Bazin's analysis of cinema as the art of recording reality to the letter, Mourlet's axiomatic argument that mise-en-scène is the very building block of film was also predicated on a extreme experience of the cinema where 'the absorption of consciousness within the spectacle is called fascination: the impossibility to detach oneself from images'. ${ }^{31}$

In September 1960, the entire issue of Cahiers du cinéma was devoted to Mac-Mahon fetish auteur Joseph Losey, a moment which marked the peak and the end point of the controversial influence of the Mac-Mahon school. According to Antoine de Baecque and Noël Herpe, this episode led to a crisis at Cahiers du cinéma and the replacement of Eric Rohmer, who was blamed for the ideological slip-up of having sympathy for the reactionary dogmatic tenets of the Mac-Mahoniens..$^{32}$ The writers of the Mac-Mahon group thus moved elsewhere. In 1961, Michel Mourlet became editor with Jacques Lourcelles of Présence du cinéma. The Mac-Mahon pantheon was furthered enshrined with special issues dedicated to the 'Four Aces' noted above and a select - albeit eclectic - group of directors representing the 'purity of mise-en-scène': Vittorio Cottafavi, Don Weiss, Blake Edwards, Riccardo Freda, Raoul Walsh, Joseph L. Mankiewicz, Samuel Fuller, John Ford, Allan Dwan, Jacques Tourneur and Cecil B. DeMille. The journal folded in 1967 . 
Behind this disparate list of directors was an oppositional programme: Présence $d u$ cinéma stood against both Italian neo-realism, which had been lionised by left-wing critics and André Bazin, and modern European art cinema. It denigrated 'those intellectuals without taste, without judgement and genius that populate coffee shops, film journals and certain ciné-clubs, drunk on culture and politics' and complained that 'after Fellini, after Bergman, now it is Antonioni and Resnais that we have to suffer'. ${ }^{33}$ Présence du cinéma championed the spectacular neo-mythological B-movies ${ }^{34}$ of Ricardo Freda and Vittorio Cottafavi that had been discovered in local fleapits between 'Belleville and la Porte Saint-Martin'. ${ }^{35}$ Cottafavi offered a radical aesthetic of libidinal fascination where the spectator's attention was fixed 'on the passage between the calm and the storm'. Comparing the mise-en-scène of these films to the mise-en-scène of the 17th-century French dramatist Racine, Mourlet argued that classical tragedy informed the way they were organised 'around love, secret passion-ripping, [and] certain female faces in a world of princes'. ${ }^{36}$ Riccardo Freda, on the other hand, was 'a man alone' amid Italian cinema's neo-realist moment, a director lauded for a mise-en-scène where 'once decor is seen to logically include the actions that take place within it, everything will be said and known and the rest, themes, psychology, moral judgement, become pointless'. ${ }^{37}$ French cinema and especially the New Wave were violently rejected, offering a catalyst for more politically motivated formalist arguments. ${ }^{38}$ Despite such extreme views that went against the critical consensus of the time, the Mac-Mahoniens exerted an enormous influence beyond film fanatics. Joseph Losey, for instance, has frequently acknowledged how the Parisian release of Time without Pity in June 1960 by the group affiliated with the Mac-Mahon 'was a turning point' in a career he owed 'to the Mac-Mahon' ${ }^{39}$

Jean-Luc Godard's A bout de souffle/Breathless (1960) remains a homage to the aesthetics of the Mac-Mahon. There is the physical presence of the Mac-Mahon itself when Patricia (Jean Seberg) ducks into the cinema to escape the police and we then hear dialogue from Otto Preminger's Whirpool (1949). There is, too, the participation of Pierre Rissient as co-director (he was also assistant director to Claude Chabrol on Les Cousins [1959]) and there are numerous uncredited appearances by famed MacMahoniens: Michel Mourlet as the studio photographer, Michel Fabre, who plays one of the two detectives pursuing Michel Poiccard (Jean-Paul Belmondo); Jacques Serguine, who is one of the spectators at the Mac-Mahon; and the owner of the Mac-Mahon himself, Emile Villion, who appears outside the cinema with the cashier. Godard's closeness to Mourlet and the Mac-Mahoniens is illustrated further by Le Mépris/Contempt (1963). In a piece written in 2011, 'L'Affaire Godard-Bazin', Mourlet specifically points out that Godard's famous spoken epigraph which begins the film -"'cinema", said André Bazin, "substitutes for our gaze a world more in harmony with our desires"' - was, as already seen, actually taken from his 1959 article 'Sur un art ignoré' published in Cahiers $d u$ cinéma. ${ }^{40}$ The looming presence of Fritz Lang in this film also points to the Mac-Mahon cult of Lang against Hitchcock and specifically to Moonfleet (1955), released exclusively at the Mac-Mahon in March 1960, when MGM refused to distribute it in Paris. ${ }^{41}$ Moonfleet was a core film of this strand of cinephilia, most crucially for Serge Daney, who joined Cahiers du cinéma in the mid-1960s. ${ }^{42}$ Finally, the continuing influence of

\section{Michel Mourlet} Sur un art ignoré

\section{La mise en scène comme langage}

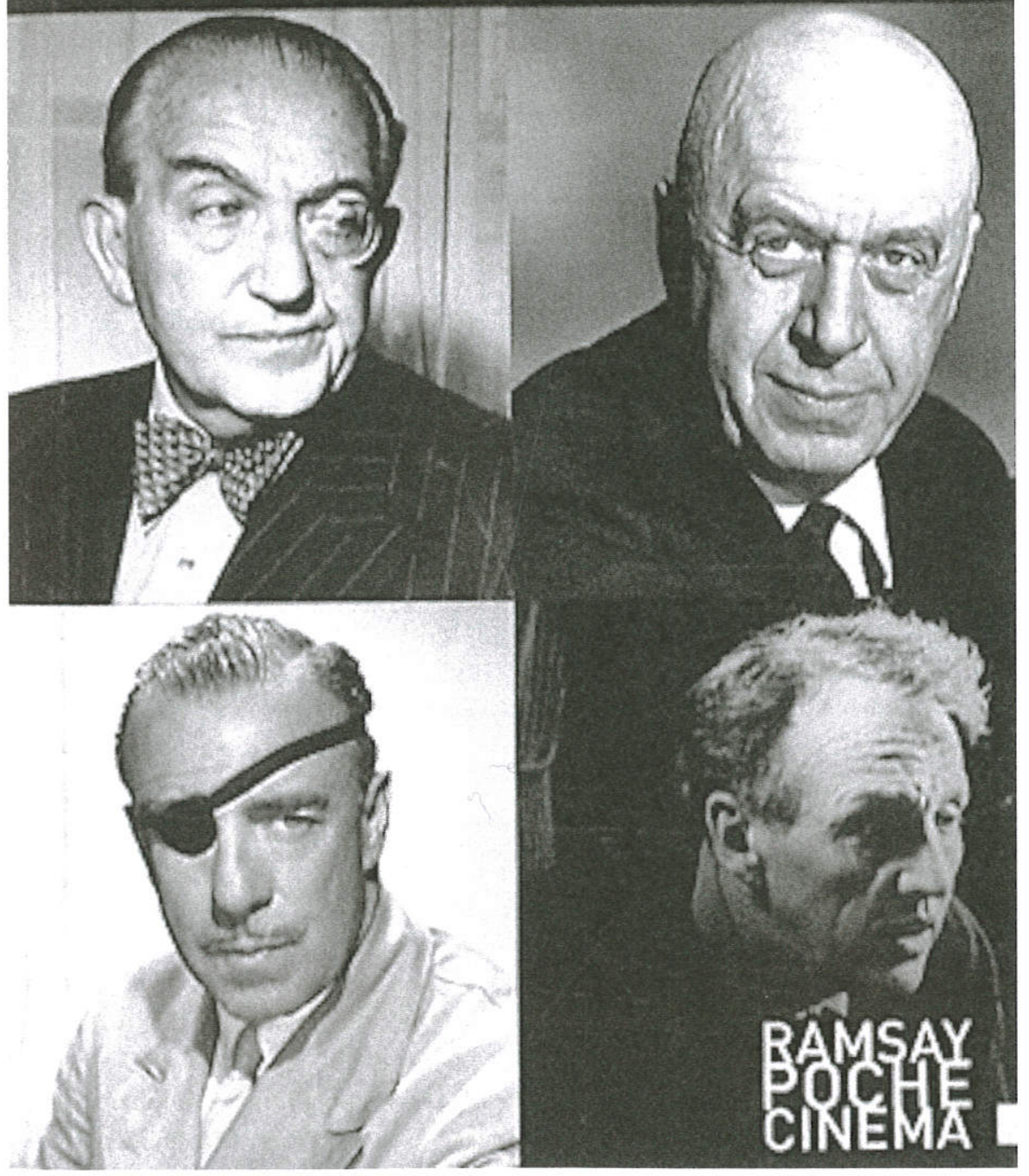

The cover of Michel Mourlet's 2008 Ramsay edition of Sur un art ignoré, featuring the 'four aces' of the Mac-Mahon: (clockwise from top left) Fritz Lang, Otto Preminger, Joseph Losey, Raoul Walsh. 
this key moment in the history of cinephilia figures in the revisionist portrayal of its political background in Liberty Belle, directed in 1983 by the former Cahiers du cinéma critic Pascal Kané. Set in early 1960s Paris during the intensification of the Franco-Algerian war, the conflict between proponents of Algerian independence and those against is played out on the terrain of cinephilia and the symbolic critical split between the 'Hitchcocko-Hawskiens' and the 'Mac-Mahoniens'. Julien (Jérôme Zucca) and Gilles (Philippe Caroit) are two young students from the Lycée Chaptal, on the boulevard des Batignolles, whose friendship is challenged by their divergent cinematic tastes and political inclinations. Julien is a Cahiers du cinéma reader who admires Fellini, Bergman and Antonioni; Gilles reads Présence du cinéma and 'would give up all of Antonioni for a single shot in Walsh'. While Gilles is actively involved with the right-wing OAS (Organisation Armée Secrète, the paramilitary organisation against Algerian independence), Julien will end up as a courier for the FLN (Algerian Liberation Front)

Today, cinephilia has shifted with the normalisation of the internet and now the passionate love of film takes many different forms, tastes and practices. ${ }^{43}$ Yet, Paris is still famous as the capital city offering the widest range of different films to watch in the world. When Emile Villion died in 1968, the Mac-Mahon was eventually taken over by Alex Brucker, who, "content to "lose money with Lubitsch" initially followed a programming philosophy that would be "le pur et dur, almost flagellatory"', though he would 'gradually shift his principles by linking treasures from the classical era with more recent fare'. ${ }^{44}$ Since ownership transferred to Vincent Bolloré's holding group in 2000, this eclectic range of programming has increased, combining retrospectives of Hollywood classics with contemporary releases and special previews, film festivals and renting the venue for private screenings, debates and receptions. ${ }^{45}$ In 2000, the Mac-Mahon was entirely renovated, thus preserving its 'Broadway style' art deco façade, as well as its small lobby and original 1940s ticket booth. As Danny Fairfaix points out, 'the aura of a bygone epoch continues when the spectator enters the cinema's single salle, with its 150 red velvet seats, gilded fittings and starry blue cupola overhead'. ${ }^{46}$ In a time of multiplex cinemas, this antiquated interior design framed by two Roman statues helps to foster a close proximity between both spectators and the screen, and projects one back to a cinephile past. As I recently took my seat for the screening of a $35 \mathrm{~mm}$ print of Notorious (Alfred Hitchcock, 1946) in the intimate surroundings of the Mac-Mahon's darkened auditorium and the credits started to roll, I was immediately immersed in the images projected before me; no advertising, no fancy trailer; 'cinema, alone' 47 as the film unfolded. In this sense, the Mac-Mahon still stands as a space of cultural remembrance, a site charged with a past. It will be forever linked to the ritual of filmgoing and the experience of a certain kind of filmmaking as well as the home of the cinephile spectator, if no longer that of a coterie of film critics. In other words, the Mac-Mahon remains both a symbolic and physical embodiment of the enduring presence of cinema in the historical memory of the city and a monument to the unique and enduring relationship between Paris and cinephilia.

I would like to thank the head of programming, Bruno Vincent, for both his warm welcome during my visit and for kindly providing the photograph of the cinema that illustrates this chapter.

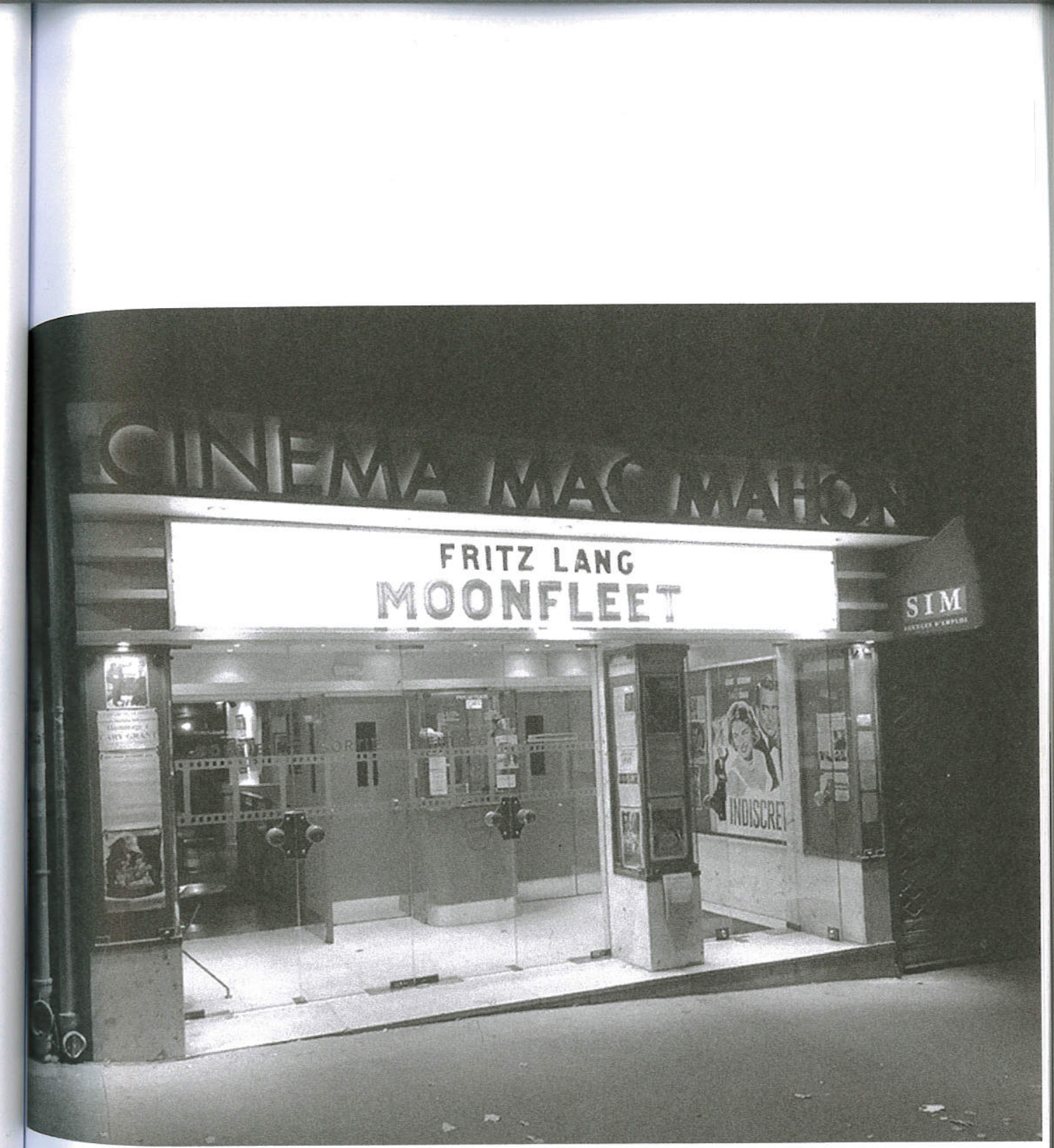

A 2015 screening of Moonfleet (Fritz Lang, 1955) at the Mac-Mahon. 
1. Noël Burch, 'Cinéphilie et masculinité (I)', Iris, no. 26 (Autumn 1998), pp. 191-6 and Geneviève Sellier, 'Cinéphilie et masculinité (II)', Iris, no. 26 (Autumn 1998), pp. 197-206.

2. Pierre Bourdieu, Distinction: A Social Critique of the Judgment of Taste (London: Routledge \& Kegan Paul, 1984).

3. Pierre Nora, Realms of Memory: The Construction of the French Past, three volumes (New York: Columbia University Press, 1996-98).

4. Laura Mulvey, 'Some Reflections on the Cinephilia Question', Framework. The Journal of Cinema and Media, vol. 50, nos. 1 and 2 (Spring and Autumn 2009), p. 190.

5. Antoine de Baecque, La Cinéphilie. Invention d'un regard, histoire d'une culture, 1944-1968 (Paris: Fayard, 2003), p. 23.

6. See, for instance, Richard Roud, A Passion for Film: Henri Langlois and the Cinémathèque Française (London: Secker \& Warburg, 1983); Pierre Barbin, La Cinémathèque française: inventaire et légendes, 1936-1986 (Paris: Vuibert, 2005)

7. See Christophe Gauthier, La Passion du cinéma. Cinéphiles, ciné-clubs et salles spécialisées à Paris de 1920 à 1929 (Paris: AFRHC/Ecole de Chartres, 1999).

8. According to Louis Delluc, the camera and the screen transformed the 'real', revealing something beyond appearances: 'the miracle of the cinema is that it stylizes without altering the plain truth', while for Jean Epstein, this ineffable quality of the moving image, photogénie, was impossible to pin down: 'one runs into a brick wall trying to define it'. See Richard Abel, French Film Theory and Criticism, 1907-1939, Volume I: 1907-1929 (Princeton, NJ: Princeton University
Press, 1988), pp. 110, 243.

9. Ibid., p. 103.

10. Paula Amad, "'Objects Become Witnesses": Eve Francis and the Emergence of French Cinephilia and Criticism', Framework. The Journal of Cinema and Media, vol. 46, no. 1 (Spring 2005),
pp. 56-73.

11. Founded by Jean Curtelin and Michel Parsy in 1959.

12. Roland Barthes, 'Leaving the Movie Theatre', in The Rustle of Language, trans. Richard Howard (New York: Hill and Wang, 1986), pp. 345-6.

13. Paul Willemen, Looks and Frictions: Essays in Cultural Studies and Film Theory (Bloomington: Indiana University Press, 1994), p. 236.

14. Gauthier, La Passion du cinéma, p. 249.

15. Ibid., p. 263.

16. Rosemary Wakeman, The Heroic City: Paris 1945-1958 (Chicago, IL, and London: University of Chicago Press, 2009), p. 204; Virginie Champion, Bertrand Lemoine and Claude Terraux, Les Cinémas de Paris, 1945-1995 (Paris: Délégation à l'action artistique de la ville de Paris, 1995), p. 29 17. Jeander, 'Les Ciné-clubs', in Denis Marion (ed.), Le Cinéma par ceux qui le font (Paris: Fayard,
1949), p. 392. 18. Christian-Marc Bosséno, La Prochaine Séance. Les français et leurs cinés (Paris: Gallimard,
1996), pp. 19-20.

9. In Richard Neupert, A History of French New Wave Cinema (Madison: University of Wisconsin
Press, 2002), p. 11.
20. The Cinémathèque has travelled widely across Paris. It was located at 7 avenue de Messine (8th arrondissement) from 1948 to 1955, when it moved to 29 rue d'Ulm in the 5th arrondissement. It moved again in 1963 to the Palais de Chaillot, place du Trocadéro (16th arrondissement), and finally in 1998 to 51 rue de Bercy in the 12th arrondissement.

21. Jacques Serguine, 'Education du spectateur ou l'école du Mac Mahon', Cahiers du cinéma, no. 111 (September 1960), p. 44

22. Michel Mourlet, 'Sur un art ignoré', Cahiers du cinéma, no. 98 (August 1959), p. 27

23. The name of this group, originating from Roger Nimier's novel Le Hussard bleu/The Blue Hussar was coined by the literary critic Bernard Frank in an article published in 1952 in Les Temps modernes.

24. Antoine de Baecque, Camera Historica. The Century in Cinema, trans. Ninon Vinsonneau and Jonathan Magidoff (New York: Columbia University Press, 2012), p. 112.

25. On the Algerian War in French film journals, see Sébastien Denis, 'Les Revues françaises de cinéma face à la guerre d'Algérie', 1895, no. 42 (2004), pp. 35-56.

26. Mourlet, 'Sur un art ignoré', p. 30.

27. Ibid., p. 33.

28. Ibid., p. 34.

29. de Baecque, La Cinéphilie, p. 118.

30. Mourlet, 'Sur un art ignoré', p. 30.

31. Ibid., p. 31.

32. Antoine de Baecque and Noël Herpe, Eric Rohmer (Paris: Stock, 2014), p. 148.

33. Michel Mourlet, 'Du côté de Racine', Présence du cinéma, no. 9 (December 1961), p. 29.

34. Richard Dyer argues that the heroic masculinity of the peplum invokes colonial and fascist subtexts and a reactionary patriarchal status quo. See Richard Dyer, 'The White Man's Muscles', in White (London and New York: Routledge, 1997), pp. 145-83.

35. Michel Mourlet, 'Prélude à Cottafavi', Cahiers du cinéma, no. 99 (September 1959), p. 62. The first occurrence of the term 'peplum', according to Claude Aziza, was in the cinephile circle of Bertrand Tavernier's Nickel Odéon ciné-club who looked for B-movies in the Grands Boulevards cinemas. See Claude Aziza, 'Le Mot et la chose', CinémAction, no. 89 (1998), p. 10.

36. Mourlet, 'Du côté de Racine', pp. 29-32.

37. Jacques Lourcelles, 'Un homme seul', Présence du cinéma, no. 17 (November 1963), p.6.

38. Jean Curtelin, 'Sergent Croft, petit frère', Présence du cinéma, no. 13 (May 1962), p. 17.

39. Joseph Losey in Michel Ciment, Le Livre de Losey (Paris: Editions Stock, 1979), pp. 179-80.

40. 'L'Affaire Godard-Bazin', in Michel Mourlet, L'Ecran éblouissant. Voyages en Cinéphilie 19582010 (Paris: Presses Universitaires de France, 2011), pp. 201-5.

41. Jacques Lourcelles, Dictionnaire du cinéma. Les films (Paris: Editions Robert Laffont, 1992), p. 986.

42. The title of Daney's L'Exercise a été profitable, Monsieur (Paris: P.O.L, 1993) is taken from a line of dialogue in the film. See Persévérance (Paris: P.O.L, 1994), p. 61.

43. See Laurent Jullier and Jean-Marc Leveratto, 'Cinephila in the Digital Age', in lan Christie (ed.), Audiences: Defining and Researching Screen Entertainment Reception (Amsterdam: Amsterdam University Press, 2012), pp. 143-54. 
44. Daniel Fairfax, 'Le Mac Mahon', in Jean-Michel Frodon and Dina lordanova (eds), Cinemas of Paris (St Andrews: St Andrews Film Studies, 2016), pp. 330-1.

45. www.cinemamacmahon.com (accessed 8 April 2016).

46. Fairfax, 'Le Mac Mahon', p. 331

47. "In relation to the "cinema, alone", it is therefore at the very time when its uniqueness began to disappear that the consciousness and love of cinema were first forged', Raymond Bellour, "'Cinema, Alone"/Multiple "Cinemas"', trans. Jill Murphy in Alphaville: Journal of Film and Screen Media, no. 5 (2013). Available online: www.alphavillejournal.com/Issue5/HTML/ArticleBellour. html (accessed 3 September 2015).

\section{Beyond the Flâneuse: The Uniqueness of Cléo de 5 à 7}

\section{Jennifer Wallace}

Agnès Varda's New Wave film Cléo de 5 à $7 /$ Cleo from 5 to 7 (1962) tells the story of 90 minutes in the life of a Parisian pop singer, Cléo (Corinne Marchand), who is anxiously awaiting the results of a medical test on the longest day of the year. In the process, she moves through various parts of the city, using different forms of transportation. Contemporary critics praised Varda for deftly intertwining a fictional narrative within a documentary-style depiction of a recognisable Paris, ${ }^{1}$ but it is only more recently that the film's status has risen, with two English-language monographs on the subject, and it has become a popular choice for analysis in areas such as feminist film studies, auteur cinema and cinema and the city. One of the most prevalent references in writings on the film is the figure of the flâneuse. Sandy Flitterman-Lewis, Janice Mouton, Valerie Orpen, Steven Ungar and Mark Betz have all discussed Cléo as the embodiment of a New Wave flâneuse, with each writer attributing various components of flânerie to her character according to their own interpretations. My aim in this chapter is to challenge the default labelling of Cléo as flâneuse. I believe that the film demonstrates such a rich and varied range of travelling around the city that to continuously refer to the term flânerie is to misrepresent the complexity of Cléo's journey and her transformation as a character. I also wish to establish the uniqueness of Cléo de 5 à 7 in its treatment of the central female character in comparison to other contemporary examples. As I will illustrate, the film highlights a positive transformation for a woman in the city - something that is rarely seen in both New Wave and popular cinema of the early 1960 s.

In her seminal work on Varda, Flitterman-Lewis compares Cléo to a 'Baudelairean flâneur' as she 'glides' through the Dôme café, overhearing snatches of conversation related to art and politics from other patrons around her. ${ }^{2}$ Mouton argues that Cléo manages to break the cycle of objectification in becoming a flâneuse who does not fall into the same trap of objectification as a flâneur. She is not trying to possess the city or its people, she is responding to it as an observer for the first time. ${ }^{3}$ Orpen is the author who most successfully problematises Cléo as a flâneuse in her monograph on the film; however, she remains persuaded that Cléo moves towards flânerie in the latter half of the film because she believes that Varda is consistently aware of 'Paris as the locus of modernity'4 and because Cléo's outfit change into a black dress and sunglasses is reminiscent of the flâneur blending in. ${ }^{5}$ Ungar sees Cléo de 5 à 7 as the first treatment of the urban female walker, ${ }^{6}$ and finally Betz applies a racial reading to the film in arguing that the image of the flâneuse in New Wave cinema is linked to 1960 s colonial discourse. ${ }^{7}$ 